\title{
Old Nobility versus New: Colonna Art Patronage during the Barberini and Pamphilj Pontificates (1623-1655)
}

\author{
Christina Strunck
}

One of the characteristics of Roman 'court culture' was the powerful social dynamic created by its celibate oligarchy: again and again, men from relatively obscure families were appointed cardinals and rose to a rank almost equal to that of kings; ${ }^{1}$ again and again, popes helped the secular members of their family attain high positions in society. The Congregatio super executione mandatorum contra Barones Status Ecclesiastici (founded in 1596) enabled the papal families to purchase the often heavily indebted feudal states of the ancient nobility, thereby also acquiring the noble titles that went with them. ${ }^{2}$ Since social status had to be maintained by conspicuous consumption, the old Roman nobility found it increasingly difficult to keep pace with the papal families, who could rely on the near-endless resources of the papal treasury.

The present study seeks to show how this situation was dealt with by the Colonna, who considered themselves to be Rome's 'First Family'. In the introduction I will discuss the basis for this claim and the factors that defined the Colonna's relationship to the papacy. I will then proceed to analyse the self-representation of the Colonna di Paliano, the main branch of the family in the seventeenth century, focusing on works of art and literature which defined Colonna identity by emphasizing the family's collaboration or conflict with the pope. ${ }^{3}$ The chosen time-frame is particularly interesting because the Colonna's relationship to the pope changed drastically after the conclave of 1644 While they had maintained close contacts with Urban VIII Barberini (1623-44), they found themselves in icy isolation under his successor Innocent $X$ Pamphilj (1644-55). How did they respond to this challenge?

\section{The Colonna, the Papacy and the Papal Families}

The Colonna family can trace its roots back to the eleventh century and is thus the oldest and most illustrious of the Roman noble families still in existence 
today. ${ }^{4}$ During the course of its eventful history, the family was noted for its readiness both to co-operate with but also to confront the papacy. Its almost proverbial opposition during the Middle Ages reached a spectacular climax under Boniface VIII, who in 1297 called for a crusade against the family. Sciarra Colonna achieved revenge a short time later when, in a union with France, he took the pope prisoner in Anagni. Only once did the Colonna have the good fortune to provide a pope themselves - Martin V (1417-31). It was his nepotism that laid the foundation for the rise of the Colonna di Paliano, who in the sixteenth century began to assume the leading role within the wide family network.

In the early Cinquecento, the Colonna produced important condottieri who certainly had no qualms about forming external political alliances with the enemies of the pope. Even an ecclesiastical dignitary like Cardinal Pompeo Colonna did not hesitate to use military force against the pope: in 1526 he captured the Vatican and plundered the residence of his great enemy Clement VII, over whom he again triumphed a year later in the Sacco di Roma. It was only when the Colonna retired from the stage of major European politics following the peace of Cateau-Cambrésis (1559) that Marcantonio II Colonna undertook the change from opponent of the papacy to its faithful servant. The cleverly orchestrated marriages of his eldest son and grandson to members of the reigning papal families were doubtlessly advantageous for the fortunes of the Colonna. ${ }^{5}$ Moreover, his ties with the papacy not only resulted in the Duchy of Paliano being elevated to a principality in 1569, but also bestowed upon Marcantonio the most glorious moment of his life: victory in the naval battle of Lepanto on 7 October 1571. This battle, in which Marcantonio served as the commander of the papal fleet, was generally seen as an epochal event, because for the first time in more than a hundred years the seemingly unstoppable westward advance of the Turks was halted. ${ }^{6}$ Pope Pius V was so elated that he honoured Colonna with a triumphal entry into Rome in December $1571^{7}$ - an extraordinary event that became a recurring theme in Colonna art patronage.

The relationship between the Colonna and the papacy was nevertheless not entirely harmonious. In 1594 Clement VIII forced the Colonna di Paliano, despite their fierce protests, to relinquish their estate of Nettuno. ${ }^{8}$ While Filippo Colonna di Paliano managed to rehabilitate the family's financial fortunes, not least through clever matrimonial alliances, ${ }^{9}$ the monetary problems of both the Colonna di Palestrina and the Colonna di Zagarolo resulted in their having to sell their most splendid possessions to the nephews of Gregory XV and Urban VIII respectively. ${ }^{10}$

Although Paliano lay within the papal state (about 50 kilometres to the east of Rome), it was considered a sovereign principality by the Colonna. Paul IV confiscated Paliano in 1556, elevated it to a duchy and gave it to his nephew Giovanni Carafa 'cum privilegiis aliis ducibus competentibus et precipue Ferrariae, Parmae ac Urbini, de iure vel consuetudine'. After the fortress 
was restored to the Colonna following the fall of the Carafa, they insisted on retaining the same privileges, a demand confirmed by both Pius V and Urban VIII. ${ }^{11}$

The strategically important position of the fortress of Paliano constituted an important power base for the Colonna. Their properties formed a belt-like buffer zone between the Spanish Regno di Napoli and the papal state. ${ }^{12}$ Thus the family alliance which Urban VIII concluded with the Colonna helped him maintain political independence in the face of heavy pressure from Spain. ${ }^{13}$ A marked shift in the balance of power occurred when, from 1646 onward, the Colonna, who had over 3,000 soldiers 'on alert' in Paliano, allowed the Spanish to pay for the defence of the fortress. ${ }^{14}$ This gave the Spanish 'a foot in the door' of the papal state and a powerful means of controlling Innocent $X$ Pamphilj's political dealings. At the same time the strong ally protected the Colonna from repercussions arising from Innocent's prosecution of the Barberini (discussed below).

Since Paliano was - at least nominally - a sovereign state like Ferrara, Parma and Urbino, the Colonna believed they had precedence over the rest of Rome's nobility. Although some seventeenth-century writers endorsed this claim, it did not go uncontested. ${ }^{15}$ Because the Colonna owned land in the Kingdom of Naples, they were vassals of the Spanish king, who had granted them the hereditary honorary title of Gran Contestabile del Regno di Napoli. As Grandi di Spagna the Colonna came into conflict with papal families such as the Borghese and Ludovisi who had also been honoured with the grandato: since all Spanish grandees were equal in rank, they refused to acknowledge the pre-eminence of the Colonna. ${ }^{16}$

This dispute erupted repeatedly in the second half of the seventeenth century on the occasion of the Chinea, the annual cavalcade with which the Spanish king presented his symbolic tribute for the Kingdom of Naples to the pope. The Contestabile Colonna's demand that he be accorded a privileged position in this procession was rejected by the other grandees. ${ }^{17}$ If the pope was well disposed towards him, he could save the Contestabile from embarrassment by summoning him as his assistant (assistente al soglio) for the day of the Chinea festivities: Colonna's duties thus provided a perfect excuse for not taking part in the cavalcade. ${ }^{18}$ If, however, the pope was hostile to the Colonna, he could ban them from the prestigious assistenza al soglio altogether (as did Innocent $X$ for the entire duration of his reign). ${ }^{19}$

Seventeenth-century treatises on etiquette show that as assistenti al soglio the Colonna and the Orsini ranked above all other Roman nobles but below a sovereign prince or a royal ambassador. ${ }^{20}$ This reflects the fact that the Colonna's claim to sovereign status was not generally accepted. In order to improve their social standing, they sought to acquire the office of a Spanish or imperial ambassador. However, both Innocent $X$ and Alexander VII refused to accredit Marcantonio V Colonna as ambassador. ${ }^{21}$ 
It can thus be concluded that the pope had considerable influence on the social status of the Colonna. He could on the one hand confirm the sovereign status of Paliano and save the Contestabile from loss of face during the Chinea cavalcade, while on the other hand he was able to prohibit the exercise of such important offices as ambassador or assistente al soglio. As their position depended on the pope's goodwill, the Colonna repeatedly sought marital unions with papal families. ${ }^{22}$

\section{Colonna and Barberini - or How to Functionalize a Family Alliance}

Just two months after the election of Urban VIII Barberini in August 1623, rumours circulated about a possible marriage between his nephew Taddeo and one of Filippo Colonna's daughters. ${ }^{23}$ Avvisi of January and February 1624 supported this. ${ }^{24}$ As the negotiations were long and complex, ${ }^{25}$ Anna Colonna and Taddeo Barberini were eventually married on 24 October $1627 .^{26}$

The wedding was without question a 'deal', one that brought advantages for both sides. Shortly before the marriage, Filippo Colonna's son Girolamo was promised a cardinalate, which he received, aged 24, in $1628 .^{27}$ This secured him social privileges, influence at the papal court and extensive financial resources. He acquired rich and important benefices, including the archbishopric of Bologna. ${ }^{28}$ Moreover, Urban VIII gave him the estate of Palazzola as a gift. ${ }^{29}$ His younger siblings also received offices and titles, ${ }^{30}$ while his father Filippo got his interest payments reduced..$^{31}$ With Urban's support, the Colonna were able to realize their claim to social precedence over the rest of Rome's nobility. ${ }^{32}$ The pope sided with the Colonna in numerous conflicts, be it quarrels about etiquette or major legal transgressions. ${ }^{33}$

Anna Colonna brought the Barberini an extremely high dowry of 180,000 scudi, though it seems only a third of it was actually paid. ${ }^{34}$ This superlative sum reflected above all the high social status of the bride. The Barberini certainly appreciated the increase in social prestige brought about by marrying into one of Rome's noblest families. This can be illustrated with a detail from Andrea Sacchi's 'Divine Wisdom' ceiling fresco in the Palazzo Barberini: in the four corners of the room, sirens, traditional emblems of the Colonna family, quite literally elevate the status of the Barberini by holding aloft their solar device. $^{35}$

Filippo Colonna is likely to have played a role in the negotiations between Taddeo Barberini's father Carlo and Francesco Colonna that led to the sale of the prestigious Colonna fiefdom of Palestrina. ${ }^{36}$ The painted decoration of a small gallery in the Palazzo Barberini celebrates this important acquisition and its accompanying princely title: the ceiling shows putti fitting Taddeo's coat of arms with the princely crown for which he was indebted to the Colonna family. ${ }^{37}$ 
When Urban VIII visited Palestrina for the first time in 1630, he attended a splendid reception in Filippo Colonna's neighbouring estate. Filippo demonstrated his military strength by staging a parade of some 3,000 infantry and 800 cavalry under the command of his son Prospero. Obviously he was prepared to take an active part in papal politics. A printed description of the festivities emphasized that Prospero Colonna was destined to follow in the footsteps of Marcantonio Colonna, who had triumphed over the Turks in the famous naval battle of Lepanto. ${ }^{38}$

It has hitherto been overlooked that in the early 1630s Lepanto was to serve as a model for a new 'crusade' under Urban VIII. In 1632 the Marquis of Monterey, acting on behalf of the Spanish king, called upon Battista Naro, captain of the papal fleet, to establish a common flotilla to fight the Turks in the Levant. By the summer of 1633 the undertaking had assumed concrete form: Naro arrived with the fully armed papal galleys in Naples to await his allies. On the basis of promises made by the Spanish, the Florentines and the Maltese, he could expect to assemble a fleet of 37 galleys; the Turks had 41 at their disposal. ${ }^{39}$ Given that galleys normally held 300 to 350 men (soldiers and rowers), this would have made for an impressive force of about 12,000 men, even if it could not compete with the numbers sent into battle at Lepanto. ${ }^{40}$ However, in the end the plan came to nothing.

While these preparations were underway, the victory of Lepanto was again extremely topical. Urban VIII called it a model for contemporaries in his 1631 preamble for the new Colonna primogenitura. ${ }^{41}$ Pius $\mathrm{V}$, who had formed the victorious Holy League, was given the title Venerabile in $1632 .{ }^{42}$ A number of publications honouring Marcantonio Colonna appeared in 1633: a Latin poem by Vincenzo Centurione, praising the battle of Lepanto, contained a call for a new crusade; Ottavio Tronsarelli's epic account foresaw a repetition of that triumph through the collaboration of the Colonna with Urban VIII; and a collection of laudatory speeches by Michelangelo Sammaruchi repeatedly praised Marcantonio's victory and advanced him as a model for contemporaries. ${ }^{43}$ It was hardly coincidental that in 1633 a printed account recalled the already mentioned military parade of 1630, in which Prospero Colonna had been styled a worthy successor to Marcantonio. ${ }^{44}$

The battle of Lepanto was also a recurring theme in the visual arts during these years. In 1632 the Colonna had the 'Fontana dei Mori' erected in Marino, the centre of one of their duchies where many participants in the battle of Lepanto had been recruited. ${ }^{45}$ From the fountain's basin rise a number of sirens who, as sea-creatures and traditional emblem of the Colonna, are particularly well suited as bearers of the central sculpture: four 'moors' chained to the base of a column. The column ('colonna', in Italian) figures on the Colonna coat of arms; thus its presence in Marino served to symbolically represent the victorious Marcantonio. ${ }^{46}$

The fountain may have been inspired by the 'Fontana dei Mori' in Livorno, erected in honour of Ferdinando de' Medici between 1617 and $1624 .{ }^{47}$ While at 


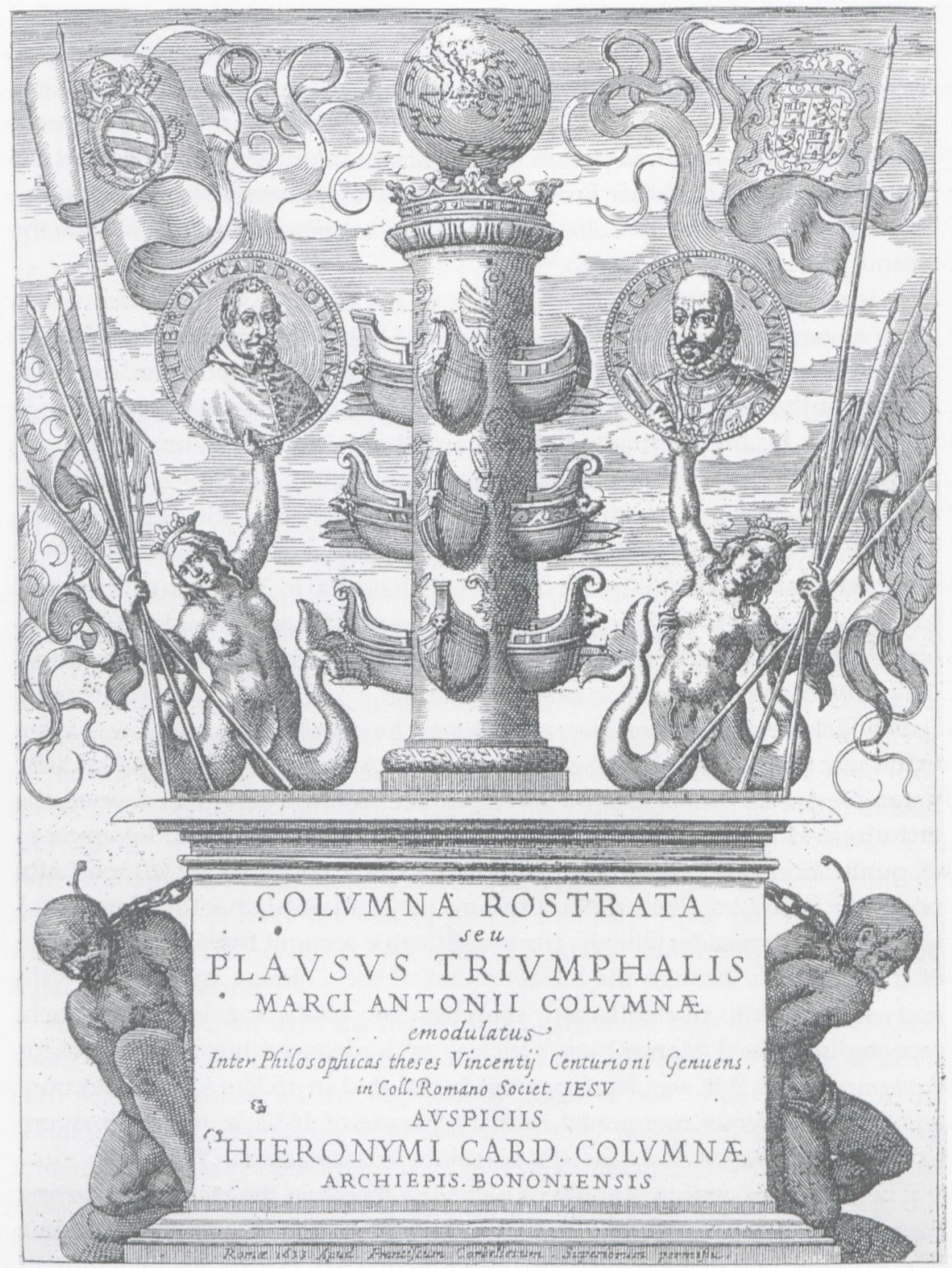

7.1 Anonymous artist, Illustrated title-page for Vincenzo Centurione's Columna Rostrata seu Plausus Triumphalis Marci Antonii Columnae (Rome, 1633), $22.5 \times 16.7 \mathrm{~cm}$, engraving

Livorno the moors are tied to the pedestal of Ferdinando's statue, at Marino the heraldic column forms the centre of the composition - a certainly less costly, though equally successful, solution because each member of the 
Colonna family could identify with the column. Therefore the monument in Marino could even be perceived as an allusion to future Colonna triumphs over the infidels.

Orientals chained to the base of a column also adorn the 1633 titlepage of Vincenzo Centurione's Lepanto poem in which he evoked a new crusade (see Figure 7.1). ${ }^{48}$ The column in the engraving differs from that in Marino in that it is the columna rostrata, a column 'pierced' by ships' prows. Such columns were erected in antiquity to celebrate naval victories. ${ }^{49}$ The columna rostrata decorated with anchors refers explicitly to a coin minted after Augustus' naval victory at Actium. ${ }^{50}$ By choosing this monument form for the title-page, Centurione programmatically referred to the established comparison between Actium and Lepanto which he elaborated in his text in order to magnify Colonna's importance. ${ }^{51}$ Moreover the triumphal monument alluded to Marcantonio's triumphal entry and thus gave visual expression to the idea that he had renewed Rome's ancient glory. ${ }^{52}$

The crown-shaped capital of Centurione's columna rostrata hints at the Colonna coat of arms featuring a crown over the column (cf. Figure 7.4). In the print, the column is topped by a globe with the word 'Lepanto' at its centre. The association of column and globe alludes to the 'World Column' (polos) which, according to ancient and early-Christian thought, supports the entire universe. ${ }^{53}$ Quite naturally this idea found its place in Colonna panegyric, duly simplified of course: Cesare Colonna called the family device 'sostegno alle sfere', and Colonna court poet Giovanni Lotti claimed that God himself had ordained the column fundament of the globe.Similarly, Centurione's title-page implies the 'fundamental' and 'supportive' role of the Colonna family in the world. Moreover, it visualizes a play on words: 'reggere il mondo' means both 'to carry the world' and 'to rule the world'. ${ }^{54}$

The title-page is related to a design by Pietro da Cortona for a thesis print dedicated to Cardinal Girolamo Colonna by Vincenzo Centurione in 1633 (Figure 7.2). ${ }^{55}$ A number of features figure in both compositions: the columna rostrata, the sirens, the captive orientals, the papal and Spanish flags. ${ }^{56}$ The portico surmounted by Girolamo's coat of arms is identifiable as 'Colonna architecture', not only because of the columns but also on account of the four crowning sculptures: these reproduce the famous ancient Dacian Captives, which were once displayed in the Loggia Colonna on the Quirinale. ${ }^{57}$ Whereas on the title-page Girolamo and his heroic ancestor appear in symmetrically arranged portrait medallions (see Figure 7.1), the thesis broadsheet shows the triumphal figure of Marcantonio beneath the cardinal's coat of arms. Like a 'new Neptune', Marcantonio rides in a carriage drawn by hippocampi. He is thus presented as a 'super-human' hero of almost divine nature.

As mentioned above, several texts of 1633 implied that the triumph of Lepanto could be 'repeated' by a joint Colonna-Barberini force. This idea 


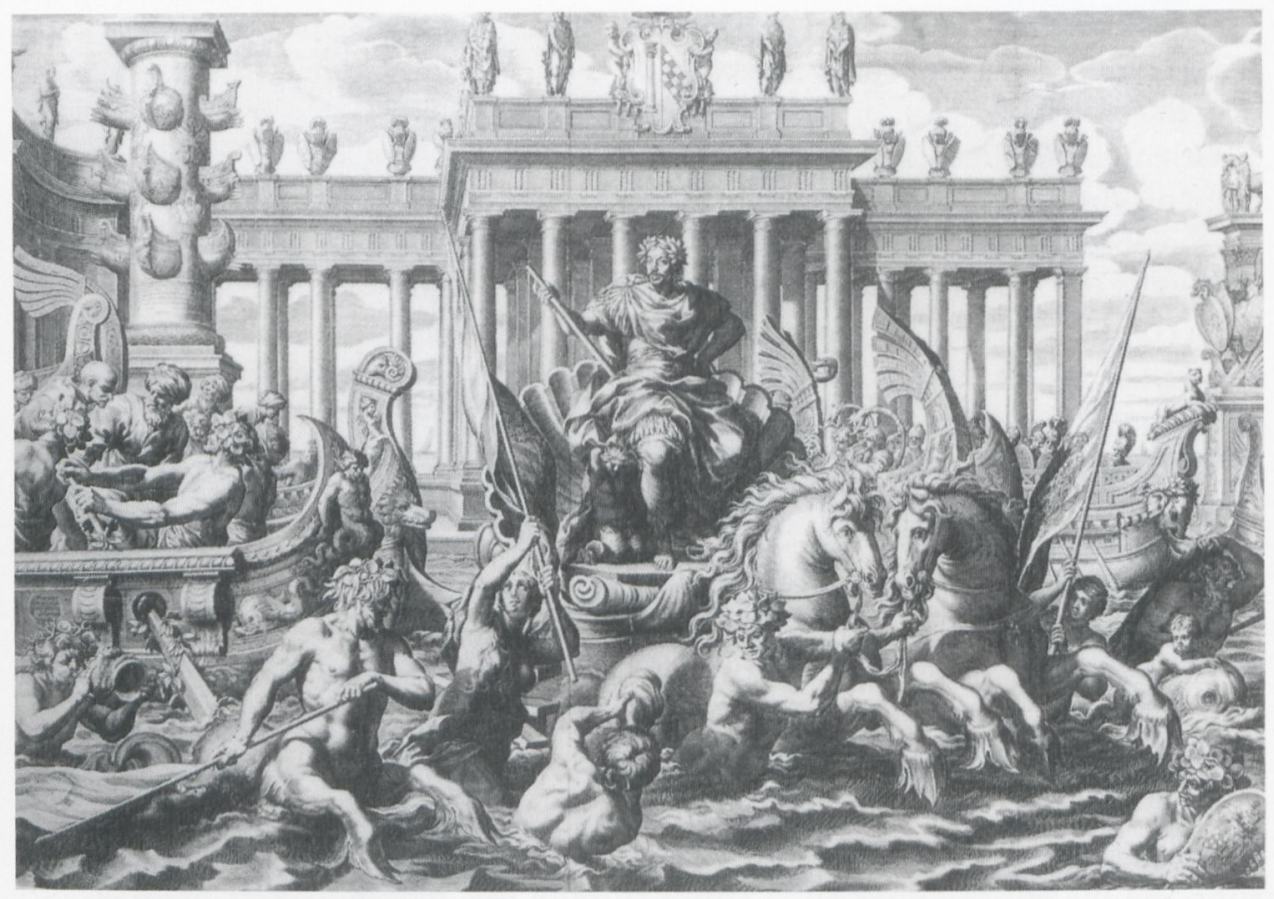

7.2 Johann Friedrich Greuter after Pietro da Cortona, The Triumph of Marcantonio Colonna, thesis broadsheet for Vincenzo Centurione, engraving, 1633

found its most spectacular expression in the so-called Giostra al Saracino, a tournament organized by Cardinal Antonio Barberini and held on the Piazza Navona in February 1634. The two presiding ladies were Anna Colonna, Taddeo Barberini's wife, and his mother, while Filippo Colonna and the head of the Colonna di Carbognano figured among the judges. A prominent member of the champion's team was the Knight of Malta, Prospero Colonna, who had sought to present himself as the successor to Marcantonio Colonna in the military parade of 1630 . Although the tournament had amorous overtones, its goal was ultimately militaristic in that the participants had to transfix the symbolic representation of a 'Saracen' ${ }^{58}$

The Giostra concluded with cannon fire and the entry of a battleship studded with Barberini and Colonna devices: columns, bees and sun symbols (Figure 7.3). Why was a ship presented at the climax of a tournament for knights on horseback? I think it served as a kind of compensation for the failure of Urban's 'crusader project' which had been pursued under the nominal patronage of the Generale delle Galere Taddeo Barberini. ${ }^{59}$ The ship demonstrated the willingness of both Barberini and Colonna to engage in a naval battle against the 'Saracens'. This implied it was not their fault that the military campaign envisaged in 1632 and 1633 had in the end come to nothing. 


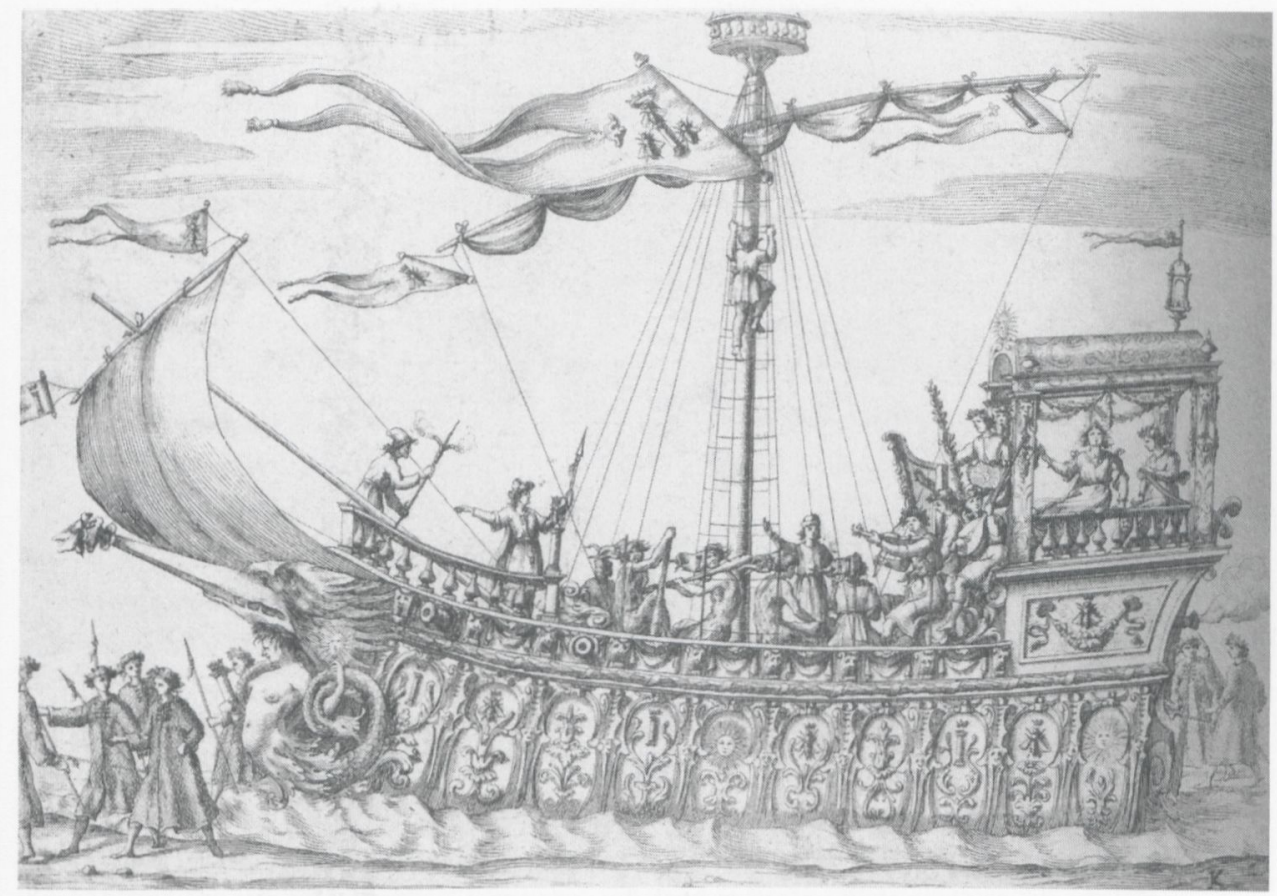

7.3 François Collignon, Ship Presented at the Giostra al Saracino on Piazza Navona, $22 \times 32.3 \mathrm{~cm}$, engraving, 1634

But just how dedicated was Urban VIII to joining forces with the Colonna and 'repeating' the victory of Lepanto? The decision to equip and mobilize the papal galleys in 1632 must be seen in the context of the Thirty Years War, and more precisely against the backdrop of the so-called Borgia crisis. On 8 March 1632, the Spanish Cardinal Borgia had dared accuse Urban VIII of favouring France over the Habsburgs because the pope had refused to grant the financial aid desired by Spain. According to Borgia, Urban supported a nation that had entered into a pact with Protestant Sweden. The pope reacted indignantly to the suggestion that his actions were detrimental to Catholic interests. The relationship remained tense for more than 18 months, until Urban adopted a more conciliatory attitude towards the end of $1633 .{ }^{60}$

Seen in this light, Spain's desire to unite with the papal fleet against the Turks in the summer of 1632 was not motivated primarily by true 'crusader ambitions', but rather by the intention to entice the pope out of his reserve with a proposal he could not refuse. In the face of Borgia's criticism that the pope favoured the enemies of Catholicism, Urban had to display his devotion to the cause of the true faith. In February 1633 he presented an extensive proposal for combating the Ottomans, in which Wallenstein was allocated an important role. ${ }^{61}$ As we have seen, letters from the summer of 1633 prove that the papal 
galleys were ready to take naval action against the Turks - though perhaps this was more a rhetorical than a military exercise. By keeping alive the possibility of a crusade, the pope sought to appear as the impartial father of Christianity and signal his readiness to co-operate with all sides, thereby silencing his critics and concealing his real political aims. ${ }^{62}$ For this reason his relationship with the Colonna was particularly welcome, since the family's propagation of the common goal of a crusade served to increase Urban's credibility. As with so many aspects of the Colonna-Barberini family alliance, this too was a 'deal': the Colonna supported papal politics and were rewarded with heightened prestige. The plan to bring about a 'second Lepanto' implied that the Colonna were still a leading force in international politics - a perception which flattered them although, in reality, it could hardly be justified.

\section{Colonna and Pamphilj - or How to Respond to Papal Disfavour}

Although in the conclave of 1644 Cardinal Girolamo Colonna had voted for Innocent $X$, the start of the Pamphilj papacy was not auspicious. ${ }^{63}$ In January 1645, the pope forced Girolamo to relinquish his position as Archbishop of Bologna, ${ }^{64}$ thus enabling the freshly appointed Cardinal Niccolò AlbergatiLudovisi, a Pamphilj relative, to take over this important office. ${ }^{65}$ Girolamo's brother Marcantonio V Colonna soon discovered that he too could not count on the pope's favour. During the entire Pamphilj papacy he was forbidden to exercise the prestigious office of assistente al soglio, which of course considerably weakened his social standing in the eyes of the other Roman nobility. ${ }^{66}$ As a means of improving his position, Marcantonio sought nomination as an imperial ambassador - but this was also frustrated by Innocent, who prohibited his assumption of ambassadorial activities. ${ }^{67}$

In the spring of 1645 , rumours began circulating about a possible trial of the Barberini for having excessively enriched themselves at the expense of the state. An investigation into the administration of public money during the Castro war was opened in June 1645. Some months later, Taddeo, Antonio and Francesco Barberini fled to France, while Taddeo's wife Anna Colonna was left in charge of the Barberini possessions in Rome. ${ }^{68}$ Because of their close ties with the Barberini family, the Colonna were now inevitably also in the line of fire'.

The official reconciliation between the Barberini and the Pamphilj took place only in 1653, when Taddeo and Anna's son Maffeo Barberini married Olimpia Giustiniani, a grand-daughter of Innocent's influential sister-in-law Olimpia Maidalchini. To mark this occasion, Maffeo's brother Carlo Barberini was made a cardinal, and Cardinal Antonio Barberini was permitted to return from Paris. ${ }^{69}$

That the Colonna were also affected by the hostility between the two papal families and socially isolated during the years of the Barberini exile is evident 


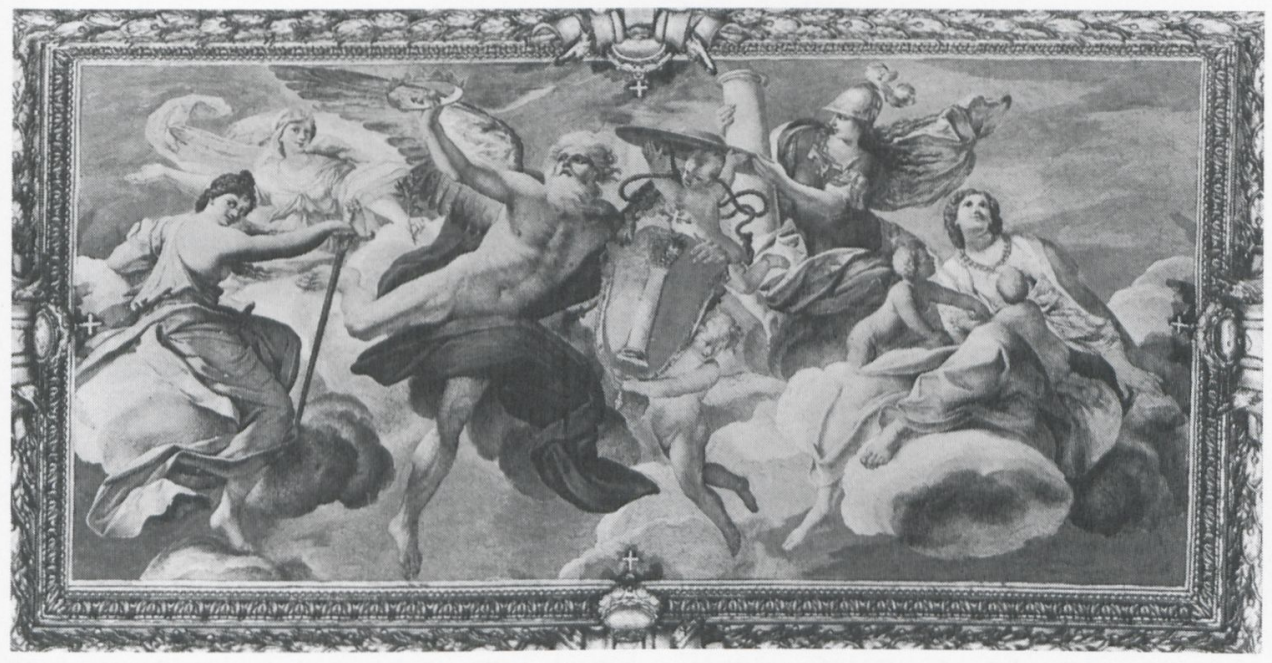

7.4 Giacinto Brandi, Time Exalting Cardinal Girolamo Colonna's Coat of Arms, ceiling fresco in the so-called Salone Turco of the Palazzo Colonna, Rome, 1649-50

from Cesare Colonna's poem, Il Trionfo di Giove. Composed on the occasion of Maffeo's marriage, the text conjures up the end of a difficult period: spring follows winter, day comes after night, a new Golden Age begins - all clear references to the Barberini's return from exile. In connection with this, the Tiber makes a votive offering to Jupiter who is to be understood as Innocent's alter ego. The Tiber asks the pope to accept an 'antica Colonna' that has been wiped clean of every possible slander. ${ }^{70}$ This indirectly confirms that tensions between the Colonna and Pamphilj did indeed exist and shows the extent to which the Colonna were dependent on papal favour, which is here requested in barely disguised form.

It has hitherto gone unnoticed that a ceiling fresco (Figure 7.4), commissioned by Cardinal Girolamo Colonna for his most impressive reception room, reflects his problematic relationship with Innocent $X$. As my research in the Archivio Colonna has shown, the painting, which can be attributed to Giacinto Brandi, was executed from 1649 to early 1650, that is during the period of the Barberini exile. ${ }^{71}$ As archpriest of the Lateran Basilica, Girolamo had the prestigious duty of opening and closing the Porta Santa during the 1650 Holy Year celebrations. ${ }^{72}$ Undoubtedly he expected to entertain numerous highranking pilgrims, whom he wished to receive in an appropriately decorated apartment. The ceiling fresco in his anticamera was to confront his guests with a programmatic representation of his own image of himself.

Chronos, the male personification of time at the centre of the composition, is surrounded by four female allegories. He carries Girolamo's coat of arms up to the heavens, thus helping him achieve the eternal fame that outlasts time, while the women personify those qualities that earned the cardinal such 
an honour. In the left foreground, the personification of Justice is juxtaposed with Charity on the right. Both embody a ruler's concern for the overall good of his subjects, bringing together the complementary aspects of firmness (Justitia) and kindness (Caritas). The background pair consists of Pax with an olive branch and armoured Fortitudo, the latter firmly associated with Colonna via her attribute, a column. A possible reading of this coupling could be: Girolamo's strength is his love of peace rather than desire for conflict; or alternatively: his strength guarantees peace. The absence of clearly religious personifications (for instance, Faith) is notable. The programme focuses on the qualities of a good ruler which are suitable both for secular and ecclesiastical princes.

As the cardinal's hat and the crown in Chronos' hand indicate, Girolamo's power stemmed not just from his high ecclesiastical office but also from his position as feudal lord. In 1639 he had inherited the Colonna primogeniture together with the largest part of the Colonna estates. ${ }^{73} \mathrm{He}$ simultaneously acquired the family's most distinguished noble titles, as he proudly announced in a medal of 1642. The obverse presented his ecclesiastical persona, while the reverse combined the image of a fortress with the inscription 'Paliani et Marini Dux Paliani et Sonnini Princeps etc. ${ }^{74}$

The fact that some ecclesiastical princes accumulated high-ranking sacred and secular titles must have infuriated cardinals of less privileged origins - such as Camillo Pamphilj, who received the purple shortly after his uncle was elected pope on 14 November $1644 . .^{75}$ Subsequently the Ceremonial Congregation (Sacra Congregatio caeremonialis, of which Francesco Barberini and Girolamo Colonna were both members) recommended that for the sake of unity, fraternity and equality, all cardinals be forbidden to decorate their coats of arms with secular insignia, especially crowns. The Congregation probably saw this as a means of winning the new pope's favour. The rule became law on 19 December 1644; thereafter a cardinal who dared have a painter or sculptor crown his arms with worldly insignia would be punished with nothing less than excommunication. Crowns were only then permitted when they formed a traditional part of the armorial bearings. ${ }^{76}$

This latter clause applied to the Colonna family. The column in their coat of arms had been allegedly surmounted by a crown since 1328 which can be observed in numerous fifteenth- and sixteenth-century representations. ${ }^{77}$ Accordingly it was also permissible after 1644; however, Girolamo had to avoid using the second crown, which the Colonna liked to place above the actual coat of arms to indicate their princely status. ${ }^{78}$

Brandi's fresco (Figure 7.4) shows how ingeniously Girolamo dealt with the new rule. Chronos carries the red shield with the crowned column over which a putto quite correctly places the cardinal's hat. But the crown which Chronos holds aloft with his right hand, and to which he looks up in admiration, appears on an even higher level than the hat. In this way the 
decree of 1644 was cleverly respected: no worldly insignia hover over the coat of arms - yet Chronos is obviously about to further exalt it with the crown he so demonstratively presents. The implication is that Time will restore Girolamo's due glory by replacing the crown on his coat of arms - an almost prophetic statement, for time was indeed on Girolamo's side, and by 1653 he was able to reclaim his old status.

Shortly after the 1653 marriage which brought about the reconciliation of the Barberini, Colonna and Pamphilj families, Girolamo made a bold move and intentionally violated the rule of 1644 . During an important ceremony in Santa Maria dell'Anima, he exhibited sumptuous wall hangings which presented his coat of arms topped not only by the cardinal's hat but also by a prince's crown. He appears to have been subsequently denounced, because in a letter to the pope he apologized for his 'oversight' in not removing the crown from the offending textiles. Probably to avoid jeopardizing their recently concluded peace, Innocent chose to impose a financial penalty rather than the designated punishment of excommunication. ${ }^{79}$

This incident shows the importance that Girolamo Colonna placed on displaying the crown above his arms, and his unwillingness to accept the Ceremonial Congregation's verdict - even though he himself (nolens volens!) had been party to that decision. He apparently viewed the 1644 decree as an attempt by the pope to reduce the status of the old noble families, and therefore sought ways of circumventing the problematic ruling. This attitude is evident not only from Brandi's fresco but also characterizes two other works executed in the context of the 1650 Holy Year.

In order to commemorate his prominent task of opening and closing the Porta Santa of the Lateran basilica, Girolamo had a medal minted which depicts on the obverse the Porta Santa, surrounded by the inscription 'Ann(o) Iub(ilaei) MDCL / Innocentius X Pont(ifex) Max(imus) VII'. On the reverse the inscription 'Hieronymus S(acrae) R(omanae) E(cclesiae) Card(inalis) Columna S(acro) S(anctae) Lateranen(sis) Bas(ilicae) Archip(resbyter) aperuit et clausit' is placed centrally, framed by various Colonna devices (four chequerboard bands referring to the coat of arms of Girolamo's mother, Lucrezia Tomacelli, two sirens and two crowned columns). ${ }^{80}$ By having individual heraldic elements, rather than his full coat of arms, represented, Girolamo could employ the crowned columns twice without needing to deal with the tricky issue of the crest crown of the shield.

Another such sophisticated strategy distinguishes the engraved titlepage of Ferdinando Ughelli's collection of biographies of Colonna cardinals (Figure 7.5), a publication dedicated to Girolamo in $1650 .{ }^{81}$ Within a fictitious architecture - naturally a play on the Colonna name - the book's title appears written on a curtain, which is surmounted by the cardinal's arms. The surrounding cartouche is cut off by the top border. Even though the design once again seemingly conforms to the papal ban on adding secular insignia, it hints at Girolamo's rejection of this regulation: by cutting off the upper part 


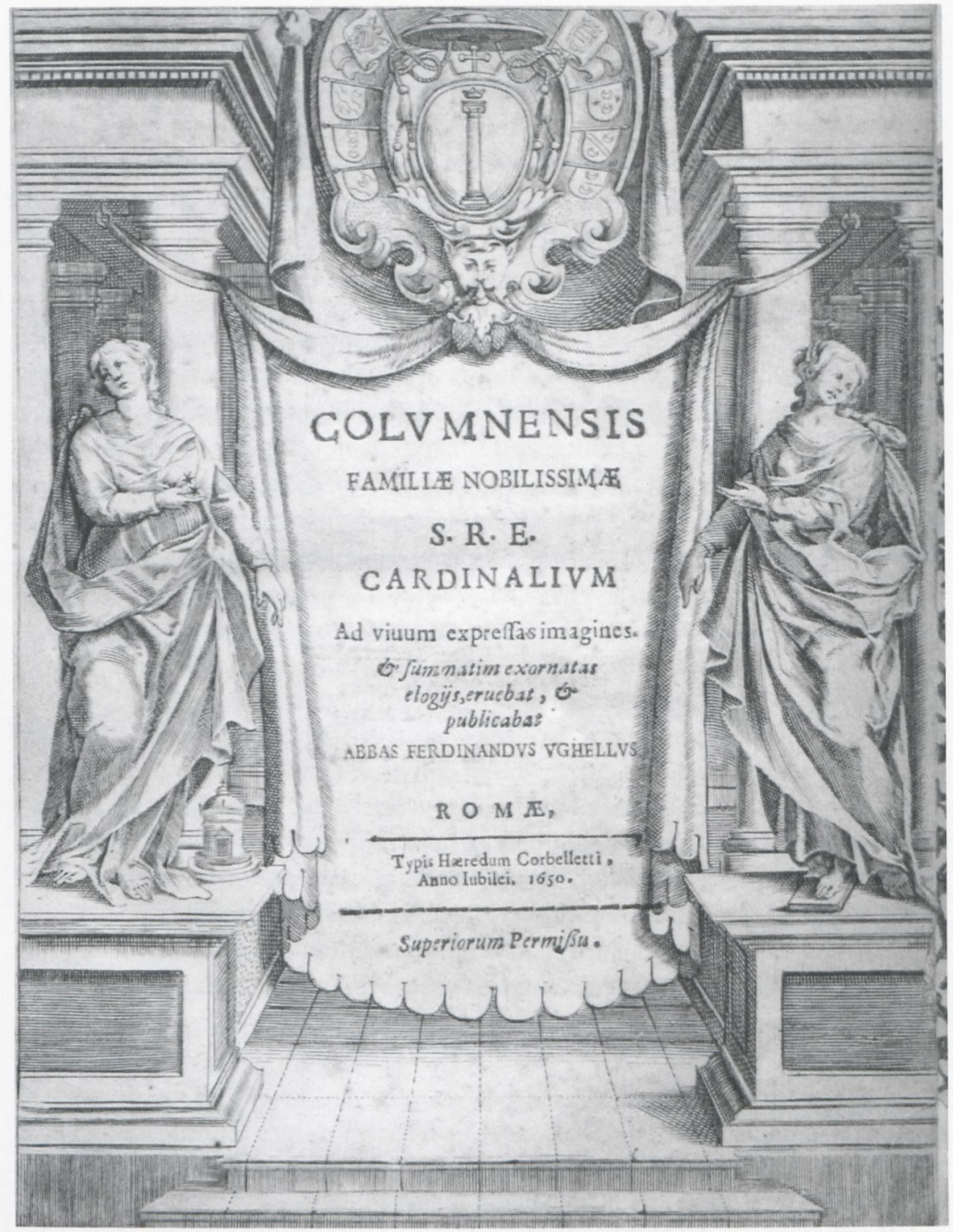

7.5 Anonymous artist, Illustrated title-page for Ferdinando Ughelli's Columnensis Familiae Nobilissimae S. R. E. Cardinalium Ad vivum expressas imagines (Rome, $1650), 23.5 \times 17.5 \mathrm{~cm}$, engraving

of the coat of arms in such an obvious way, the print draws attention to the fact that something has been omitted. It is left to the viewer to complete the missing element by imagining the crown.

While this title-page suggested that Girolamo Colonna did not entirely respect the authority of the pope in ceremonial matters, the publication as a whole 
implicitly questioned the pontiff's own lineage. Ughelli discussed no fewer than 17 cardinals and two popes, all of whom were allegedly members of the Colonna family. Innocent $X$ Pamphilj, who could only muster a single cardinal among his ancestors, most likely viewed these biographies with considerable displeasure. The construction of an 'ideal' Pamphilj pedigree reaching back to antiquity and embellished by fictive heroic family deeds testifies to the embarrassment caused by Innocent's relatively modest origins. ${ }^{82}$

By prohibiting secular signs of rank on a cardinal's coat of arms, Innocent sought to conceal the social inequalities among the cardinals - not least to 'protect' his own nephew Cardinal Camillo. But although Girolamo Colonna was no longer permitted to display his princely crown, the publication of Ughelli's long list of Colonna cardinals was a triumphal vindication of his family's superiority. Even setting aside their secular titles, the Colonna were still able to top the Pamphilj through their ecclesiastical dignitaries, having produced not just one pope, but two.

During the successive pontificate of Alexander VII Chigi (1655-67), the desire to outdo the Pamphilj again became evident in the design of the Galleria Colonna (begun in 1661) which combined in a 'superlative synthesis' features from two Pamphilj galleries: the unusually spacious architecture imitated almost to the letter a now destroyed gallery in the Palazzo Pamphilj on the Corso, while the pictorial decoration of the vault took inspiration from Cortona's frescoes in the Galleria Pamphilj at Piazza Navona. The Colonna frescoes glorifying the victory of Lepanto stressed Marcantonio Colonna's collaboration with the papacy, but at the same time they highlighted the fact that the Pamphilj lacked a comparable hero among their own ancestry, and consequently had to decorate their gallery with a fictive epic hero.

Finally, nothing less than a throne room was added to the Galleria Colonna in order to impress the (much disputed) sovereign status of Paliano on the newly-rich papal families. While the Colonna's position in Roman society was increasingly contested, their artistic self-representation became ever more grandiloquent. ${ }^{83}$

In conclusion it can be said that in the course of the sixteenth and seventeenth centuries, the Colonna (and the old Roman nobility as a whole) experienced a loss of power which was subtly contested through their art patronage. During the Barberini pontificate, the Colonna still sought to regain their former role in international politics by participating in Urban's plans for a new 'crusade' - a project doomed from its outset, but all the more vividly celebrated both in literature and in the visual arts. Innocent X Pamphilj made it clear to the Colonna that they depended on his goodwill - yet instead of resignation, they responded with thinly veiled criticism clad in works of art. Although a papal decree of 1644 tried to diminish the status of 


\section{cardinals from the high nobility, Girolamo Colonna developed sophisticated strategies of circumventing the problematic ruling in order to demonstrate the pre-eminence of his family.}

\section{Notes}

1. Cardinals were regarded as 'simili a' Re': J.B. Scott, Images of Nepotism: The Painted Ceilings of Palazzo Barberini (Princeton, NJ: Princeton University Press, 1991), p. 5; M. Völkel, Römische Kardinalshaushalte des 17. Jahrhunderts. Borghese - Barberini-Chigi (Tübingen: Boehlau Verlag Historische Anthropologie, 1993), p. 328.

2. V. Celletti, Gli Orsini di Bracciano. Glorie, tragedie e fastosità della casa patrizia più interessante della Roma dei secoli XV, XVI e XVII (Rome: Fratelli Palombi, 1963), pp. 205, 209-10, 213-15; A.C. Gampp, Die Peripherie als Zentrum. Strategien des Städtebaus im römischen Umland 1600-1730. Die Beispiele Ariccia, Genzano und Zagarolo (Worms: Wernersche Verlagsgesellschaft, 1996), pp. 26-7, 45-6, 253, 270.

3. I will also consider some 'indirect' Colonna commissions (works dedicated to them). According to seventeenth-century practice, a dedication implied not only the dedicatee's approval, but often also his financial support: see I. Herklotz, Cassiano Dal Pozzo und die Archäologie des 17. Jahrhunderts (Munich: Hirmer, 1999), p. 66.

4. This introduction is based on the following essential publications on Colonna family history: A. Coppi, Memorie Colonnesi (Rome: Salviucci, 1855); P. Colonna (ed.), I Colonna dalle origini all'inizio del secolo XIX (Rome: Istituto Nazionale Medico Farmacologico, 1927); V. Celletti, I Colonna Principi di Paliano (Milan: Ceschina Editore, 1960); A. Rehberg, 'Colonna', in V. Reinhardt (ed.), Die großen Familien Italiens (Stuttgart: A. Kröner, 1992), pp. 171-88; P. Scatizzi, 'I Colonna signori di Genazzano', in A. Bureca (ed.), Il castello Colonna a Genazzano: ricerche e restauri (Rome: Palombi, 2000), pp. 13-70. See also the entries on individual members of the family in the Dizionario Biografico degli Italiani, vol. 27, Rome: Istituto della Enciclopedia Italiana, 1982. The most recent comprehensive survey of the family history, including new source material, can be found in C. Strunck, Berninis unbekanntes Meisterwerk. Die Galleria Colonna in Rom und die Kunstpatronage des römischen Uradels (Munich: Hermer, 2007).

5. By uniting Fabrizio Colonna and Anna Borromeo in marriage, the Colonna regained their confiscated family palace, while the marriage between Orsina Damasceni Peretti and Marcantonio III Colonna resulted in Marcantonio's elevation to the rank of assistente al soglio - a title which granted him precedence over the rest of the Roman nobility (see below).

6. A. Konstam, Lepanto 1571: The Greatest Naval Battle of the Renaissance (Oxford: Osprey Publishing, 2003); H. Bicheno, Crescent and Cross. The Battle of Lepanto 1571 (London: Cassell, 2003), with a bibliography of the numerous previous publications on the subject.

7. G.B. Borino, A. Galieti and G. Navone, Il trionfo di Marc'Antonio Colonna (Rome: Miscellanea della R. Deputazione Romana di Storia Patria, 1938), pp. 1-63.

8. J. Delumeau, Vie économique et sociale de Rome dans la seconde moitié du XVI siècle, 2 volumes (Paris: E. de Boccard, 1957-59), vol. 1, p. 476.

9. Scatizzi, 'Colonna', pp. 29-30.

10. P. Waddy, Seventeenth-Century Roman Palaces: Use and the Art of the Plan (New York and Cambridge: The Architectural History Foundation / MIT Press, 1990), p. 272; Gampp, Peripherie, pp. 253-9.

11. Subiaco, Santa Scolastica, Archivio Colonna (hereafter AC) III.BB.15, n. 23, 96; Celletti, Colonna, pp. 133-4, 163; Colonna, I Colonna dalle origini, pp. 362-3. An important text documenting the social pretences of the Colonna is the seventeenth-century treatise Il Principe Duca di Palliano (AC, Miscell. II.A.12).

12. A. Costamagna, 'I principi di Paliano e alcuni momenti della committenza Colonna nella "Campagna"', in L'arte per i papi e per i principi nella campagna romana. Grande pittura del ' 600 e del '700. Volume secondo: Saggi (Rome: Quasar, 1990), pp. 5-29, particularly pp. 5-6, 22 (n. 3, n. 4); D. Armando and A. Ruggeri, 'La geografia feudale del Lazio alla fine del Settecento', in M.A. Visceglia (ed.), La nobiltà romana in età moderna. Profili istituzionali e pratiche sociali (Rome: Carocci Editore, 2001), pp. 401-45, map 'Feudi e feudatari nel Lazio' at the end of the volume. 
13. On Urban's 'anti-Spanish' politics, see the paragraph on the 'Borgia crisis' below. On the role of Paliano: F. Cirocchi, Relatione del Ricevimento fatto in Genazzano della Santità di N. Sig. Papa Urbano VIII. dall'Eccellentiss. Sig. D. Filippo Colonna Gran Contestabile del Regno di Napoli (Foligno, 1633), pp. $31-2,41-2$.

14. AC III.AA.94, n. 18.

15. G. Leti, L'Italia Regnante ò Vero Nova Descritione Dello Stato presente di tutti Prencipati, e Republiche d'Italia ..., 4 volumes (Geneva: Vincenzo Guerini, 1675), vol. 1, pp. 242-3, 306; T. Amayden, La storia delle famiglie Romane, ed. C.A. Bertini (Rome: Collegio Araldico di Roma, 1910), pp. 319-20. A full discussion of the Colonna's social position can be found in Strunck, Bernini, pp. 25-30.

16. A. Spagnoletti, Prìncipi italiani e Spagna nell'età barocca (Milan: Mondadori, 1996), pp. 56, 83-104.

17. E. Tamburini, Due teatri per il principe. Studi sulla committenza teatrale di Lorenzo Onofrio Colonna (1659-1689). Con un'ipotesi di ricostruzione del teatro 'piccolo' elaborata in collaborazione con Sergio Rotondi (Rome: Bulzoni, 1997), pp. 57, 62-3, 69, 71-5, 122, 127.

18. Tamburini, Teatri, p. 122.

19. S. Pallavicino, Vita di Alessandro VII Sommo Pontefice (Milan: Silvestri, 1843), vol. 1, pp. 250-51; P. Bruni, Principi assistenti al soglio pontificio. Orsini-Colonna. Cenni storici (Rome: Edizione privata di casa Orsini, 1963), pp. 21-2.

20. F. Sestini da Bibbiena, Il Maestro di Camera: Trattato di Francesco Sestini da Bibbiena. Di nuovo ricorretto, secondo il Cerimoniale Romano. Et in quest'Ultima impressione di diversi errori emendato (Venice: Per il Brigonci, 1664), pp. 79, 82-5; R. Ago, 'Sovrano pontefice e società di corte. Competizioni cerimoniali e politica nella seconda metà del XVII secolo', in M.A.Visceglia and C. Brice (eds), Cérémonial et rituel à Rome (XVIe - XIXe siècle) (Rome: Collection de l'Ecole Française de Rome, 1997), pp. 223-38, particularly p. 230; M.A. Visceglia, La città rituale. Roma e le sue cerimonie in età moderna (Rome: Viella, 2002), pp. 134-7, 164-5.

21. Pallavicino, Vita, vol. 1, pp. 250-55.

22. See note 5 . In the seventeenth century the Colonna sought family alliances with the Ludovisi, the Barberini and the Chigi during their respective pontificates. Marriage negotiations with the Borghese and the Pamphilj after the death of their 'family pope' were most likely motivated by the immense wealth of these families: D. Büchel, Ebenbürtig oder Parvenus? Die Heiratspolitik der römischen Papstnepotenfamilien des 17. Jahrhunderts (Lizentiatsarbeit, Fribourg, Switzerland 1996).

23. Archivio di Stato di Venezia, dispaccio di Roma al senato, filza 89, fol. 209r.

24. Ibid., fol. 549r. Biblioteca Apostolica Vaticana, Urb. lat. 1094, 10 February 1624. I am grateful to Ulrich Köchli for drawing my attention to these documents.

25. Karin Wolfe generously informed me of a manuscript which provides interesting insights into the negotiations: Paris, Bibliothèque Nationale, Manuscrits Italiens 1152, fol. 302r.

26. Coppi, Memorie, p. 386; L. von Pastor, Geschichte der Päpste seit dem Ausgang des Mittelalters, 16 volumes (Freiburg/Rome: Herder, 1955-61), vol. 13, pp. 53, 259, 701-2; F. Hammond, Music and Spectacle in Baroque Rome. Barberini Patronage under Urban VIII (New Haven and London: Yale University Press, 1994), pp. 261-2.

27. Hierarchia Catholica Medii et Recentioris Aevi, sive Summorum Pontificum, S.R.E. Cardinalium, Ecclesiarum Antistitum Series ..., ed. P. Gauchat, Monasterii (Patavii : 'Tl Messaggero di S. Antonio', 1935), vol. 4, pp. 21-2; F. Petrucci, 'Girolamo Colonna', in Dizionario Biografico degli Italiani (Rome: Istituto della Enciclopedia Italiana, 1982), vol. 27, pp. 346-7.

28. L. Meluzzi, I Vescovi e Arcivescovi di Bologna (Bologna: La Grafica Emiliana, 1975), pp. 436-40.

29. AC III.AA.73, fol. 315.

30. AC III.BB.9, n. 22, n. 36 perg.; III.BB.10, n. 38 perg.; III.BB.15, n. 72 perg.

31. Tamburini, Teatri, p. 28, n. 5 .

32. AC III.BB.15, n. 23, n. 96; G. Gigli, Diario di Roma, ed. M. Barberito (Rome: Editore Colombo, 1994), vol. 1, p. 208; Pallavicino, Vita, vol. 1, p. 250; Waddy, Palaces, pp. 158-9; Celletti, Orsini, pp. 161-3, 236-9.

33. S. Andretta, 'Filippo Colonna', in Dizionario Biografico degli Italiani (Rome: Istituto della Enciclopedia Italiana, 1982), vol. 27, pp. 297-8; G. Benzoni, 'Carlo Colonna', in ibid., pp. 282-6.

34. T. Magnuson, Rome in the Age of Bernini (Stockholm: Almquist and Wiksell, 1982), vol. 1, p. 221. 
35. Scott, Nepotism, pp. 62-3.

36. Waddy, Palaces, p. 272. The Colonna di Palestrina had once been the main branch of the Colonna family, but lost influence during the seventeenth century - not least because of the sale of their main principality.

37. Scott, Nepotism, p. 109.

38. Cirocchi, Relatione, pp. 32-4.

39. A. Guglielmotti, La Squadra Permanente della Marina Romana. Storia dal 1573 al 1644 (Rome: Voghera, 1882), pp. $422-6$.

40. Konstam, Lepanto, pp. 18-21.

41. AC III.BB.15, n. 96.

42. Gigli, Diario, vol. 1, pp. 219, 226.

43. V. Centurione, Columna Rostrata seu Plausus Triumphalis Marci Antonii Columnae emodulatus Inter Philosophicas theses Vincentij Centurioni Genuens. in Coll. Romano Societ. IESU Auspiciis Hieronymi Card. Columnae Archiepis. Bononiensis (Rome, 1633); O. Tronsarelli, La vittoria navale (Rome: Francesco Corbelletti, 1633); M. Sammaruchi, De Excellentissima Columnensium Familia. Oratio Michaelis Angeli Sammaruchi Romani ad Magnum Comestabilem Regni Neapolitani Philippum Columnam Ducem Paliani, et Taleacotii, etc. (Rome, 1633).

44. See above, notes 13 and 38 .

45. Letter by Pompeo Castiglia (1 July 1632) in AC Marino III.KB. Miscellanea, vol. 11. A. Colasanti, Le Fontane d'Italia (Milan and Rome: Bestetti e Tumminelli, 1926), plate 248; L. Maggi, 'Fontana dei Quattro Mori', in B. Azzaro, M. Bevilacqua, G. Coccioli and A. Roca De Amicis (eds), Atlante del Barocco in Italia. Lazio 1. Provincia di Roma (Rome: De Luca, 2002), pp. 161-2.

46. On the role of sirens and columns in Colonna imagery, see E.A. Safarik, Palazzo Colonna. Con $i$ contributi di Maria Grazia Picozzi e Roberto Valeriani (Rome: De Luca, 1999), pp. 16-19, 44-6.

47. M. Tommasi, Pietro Tacca (Pisa: Edizioni ETS, 1995), p. 53.

48. Centurione, Columna.

49. O. Panvinio, Comentario dell'uso, et ordine de' trionfi antichi (Venice: Tramezzino, 1571), pp. 4v-5v; E. Nash, Bildlexikon zur Topographie des antiken Rom, 2 volumes (Tübingen: Verlag Ernst Wasmuth, 1961-62), vol. 1, p. 282.

50. The anchors distinguish the 'Augustan' columna rostrata from earlier columnar monuments. See W. Haftmann, Das italienische Säulenmonument. Versuch zur Geschichte einer antiken Form des Denkmals und Kultmonumentes und ihrer Wirksamkeit für die Antikenvorstellung des Mittelalters und für die Ausbildung des öffentlichen Denkmals in der Frührenaissance (Lipsia and Berlin: Teubner, 1939), pp. 27-8; P. Zanker, Augustus und die Macht der Bilder (Munich: C.H. Beck, 1987), pp. 50 (fig. 32b), 87.

51. On the comparison of Lepanto and Actium see P. Giustiniani, Le Historie Venetiane del Clarissimo S. Pietro Giustiniano Nobile Venetiano Di nuovo rivedute, \& ampliate, Nelle quali si contengono tutte le cose notabili, occorse dal principio della fondatione della Città, fino all'anno MDLXXV ... (Venice: Avanzo, 1576), p. 348; G. Catena, Vita del gloriosissimo Papa Pio V (Rome: Gardano \& Coattino, 1586), p. 199; Centurione, Columna, p. 5.

52. The columna rostrata had already been incorporated in two sixteenth-century monuments commemorating the victory at Lepanto: AC II.A.28, n. 17 (cfr. Borino et al., Trionfo, Appendix III/4). See also A. Di Castro, 'Rivestimenti e tarsie marmoree a Roma tra il Cinquecento e il Seicento', in A. Di Castro, P. Peccolo and V. Gazzaniga (eds), Marmorari e Argentieri a Roma e nel Lazio tra Cinquecento e Seicento. I Committenti, i Documenti, le Opere (Rome: Quasar, 1994), pp. 9-155, particularly pp. 32, 117, docs 68, 69, fig. 100. In the latter case the 'Augustan' form of the columna rostrata with anchors was adopted. See also Safarik, Palazzo Colonna, fig. 23. Strunck, Bernini, pp. 207-13.

53. H. Schade, 'Zur "beseelten Säule" als Ursprung des Gottesbildes. Ein Beitrag zur kosmologischpsychologischen Hermeneutik der älteren Kunstgeschichte', in Festschrift für Hermann Bauer zum 60. Geburtstag (Hildesheim: Olms Verlag, 1991), pp. 1-32.

54. C. Colonna, Le Colonne del Tempio dell'Eternità. Panegirico Per le Nozze dell'Eccellentiss. Prencipi Donn'Anna Colonna e Don Paolo Spinola Duca di Sesto, e Generale degl'Huomini d'Arme del Rè Cattolico in Milano. Dedicato All'Eminentiss. e Reverendiss. Prencipe D. Girolamo Colonna Cardinale Protettore 
della Maestà Cesarea (Rome, 1653), stanza 5; G. Lotti, 'Poesie del Sig. Giovanni Lotti. Consagrate all'Eccellentissimo Principe D. Lorenzo Colonna, Vicerè, e Gran Contestabile Del Regno di Napoli, \& c.', in Poesie latine, e toscane del Sig. Giovanni Lotti, date in luce da Ambrogio Lancellotti Suo Nipote ... (Rome: Per Gio. Giacomo Komarch Bohema, 1688), p. 69. A seventeenth-century poem dedicated to Lorenzo Onofrio Colonna and containing the word play 'reggere il mondo' is published in Strunck, Bernini, p. 477

55. S. Prosperi Valenti Rodinò (ed.), Pietro da Cortona e il disegno (Rome: Accademia Nazionale di San Luca-Calcografia, 1997-98), p. 182; L. Rice, 'Pietro da Cortona and the Roman Baroque Thesis Print', in C.L. Frommel and S. Schütze (eds), Pietro da Cortona. Atti del convegno internazionale, Roma-Firenze, 12-15 novembre 1997 (Milan: Electa, 1998), pp. 189-200, particularly pp. 195-7.

56. Venice, the third partner in the 'Holy League', was in both cases omitted, suppressing its important share in the victory.

57. F. Carinci, H. Keutner, L. Musso and M.G. Picozzi, Catalogo della Galleria Colonna in Roma. Sculture (Rome: Busto Arsizio, 1990), p. 14; F. Haskell and N. Penny, Taste and the Antique: The Lure of Classical Sculpture 1500-1900 (New Haven and London: Yale University Press, 1981), pp. 169-72.

58. M. Fagiolo dell'Arco, La festa barocca (Rome: De Luca edizioni, 1997), pp. 285-8; Hammond, Music and Spectacle, pp. 214-24, 270.

59. Prospero Colonna, who participated in the Giostra, had been promoted to priore of the Order of St John in 1632 and may have hoped to lead the Maltese fleet in the 'crusade' of 1633: P. Litta, Famiglie celebri Italiane. Colonna di Roma (Milan: Giusti, 1836-37), tav. IX; Guglielmotti, Squadra, pp. 385, 421-6, 429.

60. Von Pastor, Geschichte, vol. 13, pp. 432-66, 474.

61. Von Pastor, Geschichte, vol. 13, p. 467.

62. Urban had already used a similar strategy in 1625 during the Veltlin (Valtellina) crisis: M.A. Visceglia, 'Giubilei tra pace e guerre (1625-1650)', Roma moderna e contemporanea, 5 (1997), pp. 431-74, particularly pp. 445-8.

63. Von Pastor, Geschichte, vol. 14, pp. 16-22.

64. AC III.BB.9, n. 32 (13 January 1645).

65. Meluzzi, Vescovi, pp. 443-4.

66. Bruni, Principi, pp. 21-22; Celletti, Orsini, pp. 161, 236-9.

67. Pallavicino, Vita, vol. 1, pp. 250-51.

68. Von Pastor, Geschichte, vol. 14, pp. 41-5; Magnuson, Rome, vol. 2, pp. 8-10.

69. Von Pastor, Geschichte, vol. 14, p. 71; Magnuson, Rome, vol. 2, p. 15. For Antonio Barberini, see also Karin Wolfe's chapter in this volume.

70. C. Colonna, 'Il Trionfo di Giove. Panegirico per le Nozze Delli Eccellentissimi Prencipi D. Olimpia Giustiniani Pamphilii, e D. Maffeo Barberini', in La Cetera di D. Cesare Colonna Romano De' Signori di Mont'Albano. Parte Prima Dedicata alla Cesarea Maestà di Ferdinando Terzo (Rome, 1654), pp. 119-62, particularly pp. 128, 159-60, stanza 93.

71. The fresco is traditionally attributed to Giovanni Lanfranco (who died in 1647): cfr. Safarik, Palazzo Colonna, p. 30. Archival sources which date the painting to $1649 / 50$ are discussed in Strunck, Bernini, pp. 75-77. The attribution to Brandi is based on F. Baldinucci, Notizie dei Professori del Disegno da Cimabue in qua (Florence: S.P.E.S, 1975), vol. 7, p. 130.

72. Petrucci, 'Girolamo Colonna', p. 346.

73. AC III.AA.73, fols 231-9, especially fols 233-4; Celletti, Colonna, p. 206; Scatizzi, 'Colonna', pp. 30-31, 70, n. 177. Cf. Strunck, Bernini, p. 470, doc. $1653,08,00$ b.

74. Litta, Colonna (plate without pagination).

75. Von Pastor, Geschichte, vol. 14, p. 31.

76. B.B. Heim, Heraldry in the Catholic Church: Its Origin, Customs and Laws (Gerrards Cross: Van Duren, 1981), pp. 47, 168, doc. 1.

77. Rehberg, 'Colonna', p. 171; Safarik, Palazzo Colonna, figures 2, 9, 12, 19, 21. 
78. Two crowns can be found, for example, in the Cinquecento ceiling paintings of the Palazzo Colonna (Safarik, Palazzo Colonna, figures 2, 144, 170) and on the tombs of Federico, Filippo and Filippo II Colonna dating from the seventeenth and eighteenth centuries respectively (Litta, Colonna, plates without pagination).

79. III.BB. 49 , n. 62 .

80. Litta, Colonna (plate without pagination).

81. F. Ughelli, Columnensis Familiae Nobilissimae S. R. E. Cardinalium Ad vivum expressas imagines. \& summatim exornatas elogijs, eruebat, \& publicabat Abbas Ferdinandus Ughellus (Rome: Typis Haeredum Corbelletti, 1650).

82. R. Preimesberger, 'Pontifex Romanus per Aeneam Praesignatus. Die Galleria Pamphilj und ihre Fresken', Römisches Jahrbuch für Kunstgeschichte, 16 (1976), pp. 221-87, particularly pp. 231-2, 249; C. Strunck, 'Die Konkurrenz der Paläste: Alter Adel versus Nepoten im Rom des Seicento', in D. Büchel and V. Reinhardt (eds), Die Kreise der Nepoten. Neue Forschungen zu alten und neuen Eliten Roms in der frühen Neuzeit. Interdisziplinäre Forschungstagung, 7. bis 10. März 1999, Istituto Svizzero di Roma (Bern: Peter Lang, 2001), vol. 5, pp. 203-33, particularly pp. 203-4.

83. This argument, which falls outside the chronological scope of the present article, is discussed in Strunck, 'Konkurrenz', pp. 215-20; Strunck, Bernini, pp. 154-55, 237-41, 352-55; and C. Strunck, 'The marvel not only of Rome, but of all Italy: The Galleria Colonna, its Design, History and Pictorial Programme 1661-1700', in D.R. Marshall (ed.), Art, Site and Spectacle. Studies in Early Modern Visual Culture (Melbourne: The Fine Arts Network, 2007), pp. 78-102. 